\title{
Antibiotic Resistance of the Genus Aeromonas Spp
}

\section{Saavedra $\mathbf{M J}^{*}$}

Department of Veterinary Sciences, School of Agriculture and Veterinary Science, University of Trás-os-Montes e Alto Douro, Vila Real, Portugal

\begin{abstract}
Aeromonads are known to be ubiquitous in several habitats, mainly in aquatic environments and have been described in connection with fish and human diseases, also known to have relatively high antibiotic resistance. In the past few years the resistance levels of the genus Aeromonas, particularly to $\beta$-lactam antibiotics seems to be increasing. The aquaculture environment may thereby constitute a reservoir for bacterial resistance to clinically relevant antibiotics. It is, therefore necessary, for the development of new alternative chemical and natural compounds to act against these pathogenic bacteria.
\end{abstract}

Keywords: Aeromonas spp.; Antibiotic resistance; Clinical relevance

Species of Aeromonas are common inhabitants of aquatic environments and have been described in connection with fish and human diseases [1-4]. The members of this genus are known to cause bacterial infections and possess a relatively high antibiotic resistance. These are among the most common and troublesome diseases of fish and also in clinical relevant cases [5].

The pathogenicity of Aeromonas has been associated with numerous virulence factors, including the aerolysin/hemolysin group of genes, the cytotonic enterotoxins Ast and Alt [6-8], the cytotoxin encoded by the act gene [9], and a type III secretion system (TTSS) [9-11]. The TTSS is a virulence mechanism that delivers toxins (AexT among others) directly into the host cell and induces apoptosis [9]. In the past few years an increase in resistance levels of the genus Aeromonas, particularly to $\beta$-lactam antibiotics, has been observed and reported by other authors [12-15]. This evolution towards increasing levels of resistance is, in part, attributed to the production of different $\beta$-lactamases, for instance inducible $\beta$-lactamases active against penicillins, cephalosporins, and carbapenems $[13,16,17]$. The environmental incidence of resistance to $\beta$-lactam antibiotics seems to be increasing. The aquaculture environment may thereby constitute a reservoir for bacterial resistance to clinically relevant antibiotics.

The development of alternative chemical and natural compounds to act against these pathogenic bacteria is each time more of high importance, since this increasing resistance to antibiotics is a global issue of public health.

\section{References}

1. Altwegg $M$ (1999) Aeromonas and Plesiomonas In Manual of Clinical Microbiology. Edited by Murray PR, Baron EJ, Pfaller MA, Tenover FC and Yolken RH, Washington, DC: American Society for Microbiology. pp 507-516.

2. Austin B, Adams C (1996) Fish pathogens. In The Genus Aeromonas. Edited by Austin B, Altwegg M, Gosling PJ and Joseph S, Chichester, Wiley, pp 197-244.

3. Saavedra MJ, Guedes-Novais S, Alves A, Rema P, Tacão M, et al. (2004) Resistance to Beta-lactam antibiotics in Aeromonas hydrophila isolated from rainbow trout (Oncorhynchus mykiss). Int Microbiol 7: 207-211.

4. Figueras MJ (2005) Clinical relevance of Aeromonas sM503. Rev Med Microbiol 16: 145-153.

5. Figueras MJ, Alperi A, Saavedra MJ, Ko WC, Gonzalo N, et al. (2009) Clinical Relevance of the Recently described Species Aeromonas aquariorum. J Clin Microbiol 47: 3742-3746.

6. Albert MJ, Ansaruzzaman M, Talukder KA, Chopra AK, Kuhn I, et al. (2000) Prevalence of enterotoxin genes in Aeromonas spp. isolated from children with diarrhea, healthy controls, and the environment. J Clin Microbiol 38: 37853790 .
7. Chopra AK, Xu XJ, Ribardo D, Gonzalez M, Kuhl K, et al. (2000) The cytotoxic enterotoxin of Aeromonas hydrophila induces proinflammatory cytokine production and activates arachidonic acid metabolism in macrophages. Infect Immun 68: 2808-2818.

8. Sha J, Kozlova EV, Chopra AK (2002) Role of various enterotoxins in Aeromonas hydrophila-induced gastroenteritis: generation of enterotoxin genedeficient mutants and evaluation of their enterotoxic activity. Infect Immun 70 1924-1935.

9. Chacon MR, Soler L, Groisman EA, Guarro J, Figueras MJ (2004) Type II secretion system genes in clinical Aeromonas isolates. J Clin Microbiol 42 1285-1287.

10. Sha J, Pillai L, Fadl AA, Galindo CL, Erova TE, et al. (2005) The type III secretion system and cytotoxic enterotoxin alter the virulence of Aeromonas hydrophila. Infect Immun 73: 6446-6457.

11. Vilches S, Urgell C, Merino S, Chacon MR, Soler L, et al. (2004) Complete type III secretion system of a mesophilic Aeromonas hydrophila strain. Appl Environ Microbiol 70: 6914-6919.

12. Bakken JS, Sanders CC, Clark RB, Hori M (1988) Beta-Lactam resistance in Aeromonas spp. caused by inducible $\beta$-lactamases active against penicillins cephalosporins, and carbapenems. Antimicrob Agents Chemother 32: 13141319.

13. Overman TL, Janda JM (1999) Antimicrobial susceptibility patterns of Aeromonas jandaei, $A$. schubertii, $A$. trota, and $A$. veronii biotype veronii. J Clin Microbiol 37: 706-708.

14. Rowe-Magnus DA, Guerout AM, Mazel D (2002) Bacterial resistance evolution by recruitment of super-integron gene cassettes. Mol Microbiol 43: 1657-1669.

15. Schmidt AS, Bruun MS, Dalsgaard I, Pedersen K, Larsen JL (2000) Occurrence of antimicrobial resistance in fish-pathogenic and environmental bacteria associated with four Danish rainbow trout farms. Appl Environ Microbiol 66 4908-4915.

16. laconis JP, Sanders CC (1990) Purification and characterization of inducible $\beta$-lactamases in Aeromonas spp. Antimicrob Agents Chemother 34: 44-51.

17. Rasmussen BA, Bush K (1997) Carbapenem-hydrolyzing $\beta$-lactamases Antimicrob Agents Chemother 41: 223-232.

*Corresponding author: Saavedra MJ, Department of Veterinary Sciences School of Agriculture and Veterinary Science, University of Trás-os-Montes e Alto Douro, Vila Real, Portugal, E-mail: saavedra@utad.pt

Received March 27, 2012; Accepted March 29, 2012; Published April 03, 2012

Citation: Saavedra MJ (2012) Antibiotic Resistance of the Genus Aeromonas Spp. J Aquac Res Development 3:e101 doi:10.4172/2155-9546.1000e101

Copyright: $\odot 2012$ Saavedra MJ. This is an open-access article distributed unde the terms of the Creative Commons Attribution License, which permits unrestricted use, distribution, and reproduction in any medium, provided the original author and source are credited. 